\title{
INITIATING RELIGIOUS MODERATION EDUCATION \\ IN THE ERA OF MANUSCRIPT-BASED EDUCATION 4.0: HERMENEUTIC ANALYSIS OF SERAT WEDHARAGA
}

\author{
Khotijah \\ Institut Agama Islam Negeri Metro \\ Metro, Lampung, Indonesia \\ E-mail: khotijahawa34@gmail.com \\ Dedi Wahyudi \\ Institut Agama Islam Negeri Metro \\ Metro, Lampung, Indonesia \\ E-mail: podoluhur91@gmail.com \\ Nawang Wulandari \\ Institut Agama Islam Negeri Metro \\ Metro, Lampung, Indonesia \\ E-mail: nawangtaufig@gmail.com
}

Faisal Mahmoud Adam Ibrahim

Universitas Al Quran Al Karim Khartoum Sudan

Omdurman, Sudan

E-mail: faisalmahmoud29@gmail.com

\begin{tabular}{c|c|c}
\hline Received: & Revised: & Approved: \\
13/11/2021 & $24 / 11 / 2021$ & $22 / 12 / 2021$ \\
\hline
\end{tabular}

DOI : 10.32332/akademika.v26i2.3803

\begin{abstract}
Education must continue to adapt to changes to educate the younger generation for the dynamics of industrial revolution 4.0. Religious moderation is practiced in a variety of ways, most notably in education. Reintroducing the Indonesian nation's old writings is one technique to impart religious moderation instruction to the younger generation. With the richness of cultural works that Indonesia has such as ancient manuscripts, it should be able to lead people to live in harmony and peace. However, as a result of the growth of the industrial revolution 4.0, what is happening in our Indonesian life nowadays reveals that many deeds lead to violence and criminality in the name of religion. This study aims to investigate the concept of religious moderation education in the era of manuscript-based education 4.0, which is done using Serat Wedharaga's hermeneutic analysis approach. Researchers will use all available data and analysis to demonstrate how Serat Wedharaga, the work of Raden Ngabehi Ranggawarsita, presents a concept linked to moderation education, which is critical in today's society in the education 4.0 era. This research is based on qualitative data. The data sources in this study consist of two kinds of data, namely primary data sources in the form of Serat Wedharaga manuscript, and secondary data in the form of books, photos, documents, journals, and previous research results that are relevant or related to primary data and research themes. After conducting an in-depth study, it is found
\end{abstract}


that Serat Wedharaga incorporates educational principles such as andragogy education and the value of self-regulation, which includes honesty, tepasalira (tolerance), awas lan eling (cautiousness), and rejecting rumor. The educational values in Serat Wedharaga are relevant to the concept of religious moderation in the education 4.0 era.

Keywords: Religious moderation, education 4.0, serat wedharaga

\section{A. Introduction}

The Indonesian country has a very high culture, and part of it can still be found today, even though it is undergoing changes and advancements, as well as changes in thinking and knowledge growth in its society. ${ }^{1}$ Indonesia, as a multicultural country, has a large number of works in the form of old manuscripts, which contain the history and lofty values of the Indonesian nation's forefathers. ${ }^{2}$ These works can also be used as guidelines for people's lives because in ancient manuscripts there are moral values, humanity, education, and other concern. ${ }^{3}$ The writers of these works frequently use a variety of languages to convey ideals and moral teachings, as well as to portray the events that are occurring. ${ }^{4}$

It is critical to introduce historical-cultural treasures, particularly those relating to old texts for the younger generation. People should be smarter in their lives since Indonesia has a great number of literary works or ancient books that are rich in moral principles. In reality, we still deal with a lot of issues like terrorism. Assault motivation is occasionally fueled not only by external provocateurs, but also by autonomous internet access, which boosts children's bravery to carry out an individual attack, or known as a 'lone wolf' attack. ${ }^{5}$ Besides, there are also cases of KKN (Corruption, Collusion, and Nepotism), hate speech, pornography, digital crimes, and other types of crimes. The situation is the influence of the industrial revolution $4.0^{6}$ where all elements of human existence and technology are harmonized in the form of computers, providing new creative and inventive options ${ }^{7}$ apart from digital security systems.

Seeing the impact of the industrial revolution 4.0 that had an impact on the world of education, the world of education is forced to continue to adapt to changes that occur to prepare the younger generation to face the dynamics of the industrial

1 Kamidjan, "Wacana Serat Hardamudha (Kearifan Lokal Dalam Sastra Jawa)," Linguistika: Buletin Ilmiah Program Magister Linguistik Universitas Udayana 19, no. 2 (September 2012): 2, https://ojs.unud.ac.id/index.php/linguistika/article/view/9694.

2 Ken Widyatwati, "Nilai-Nilai Luhur Pujangga Jawa Dalam Serat Sana Sunu," HUMANIKA 16, no. 9 (2012): 1, https://doi.org/10.14710/humanika.16.9.

${ }_{3}$ Chinda Pandu Permana and Endang Nurhayati, "Ragam Bahasa Serat Kalatidha Serta Relevansinya Dalam Pembelajaran Bahasa Jawa Siswa SMP Negeri 7 Yogyakarta," LingTera 1, no. 1 (2014): 40, https://doi.org/10.21831/lt.v1i1.2468.

${ }^{4}$ Edy Suprayitno, "Etika Pengembaraan Ilmu Masyarakat Jawa Pada Naskah Serat Dewa Ruci Karya R. Ng. Yasadipura I Dalam Perspektif Kehidupan Modern," LINGUA : Jurnal Bahasa, Sastra, dan Pengajarannya 14, no. 2 (2017): 142.

${ }^{5}$ Elma Haryani, "Pendidikan Moderasi Beragama Untuk Generasi Milenia: Studi Kasus Lone Wolf" Pada Anak Di Medan," DUKASI: Jurnal Penelitian Pendidikan Agama Dan Keagamaan 18, no. 2 (2020): 146, https:// doi.org/10.32729/edukasi.v18i2.710.

${ }^{6}$ Majidah, Dian Hasfera, and M. Fadli, "Keterampilan Literasi Informasi Mahasiswa Dalam Menghadapi Revolusi Industri 4.0," Al-Maktabah: Jurnal Perpustakaan, Arsip Dan Dokumentas 11, no. 1 (2019): 1.

7 Delipiter Lase, “Pendidikan Di Era Revolusi Industri 4.0," SUNDERMANN: Jurnal Ilmiah Teologi, Pendidikan, Sains, Humaniora dan Kebudayaan 12, no. 2 (November 7, 2019): 29. 
revolution 4.0. Finally, the world of education creates education 4.0.8 In Indonesia, the ministry of religious affairs has organized religious moderation education because moderate religion has become a characteristic of religious people in Indonesia, which is full of plurality. ${ }^{9}$ Religious moderation is practiced in a variety of ways, including education. ${ }^{10}$ In the midst of the crisis, religious moderation through education is believed to be able to promote human civilization.

Despite the variety of Indonesia's situation, which is rich in cultural works such as ancient texts and other works, people should live in love and peace. However, current facts demonstrate that, as a result of the advancement of the industrial revolution 4.0, many activities in the name of religion lead to violence and lawlessness. As a result, conducting research related to this issue is critical. The goal of this research is to investigate the concept of religious moderation education in the era of manuscriptbased education 4.0. In this study, Serat Wedharaga's hermeneutic analysis is employed to conduct the research. The researchers will provide all of the data and analysis to demonstrate how Raden Ngabehi Ranggawarsita's Serat Wedharaga work presents a concept linked to moderation education, which is critical in today's society in the education 4.0 age.

Based on the study "The Influence of the Application of the Mataram Dance Philosophy in Javanese Classical Dance in Yogyakarta Style Towards Adolescent Self-Regulation in the Serat Wedharaga Version", 11, the researcher discusses the influence of Yogyakarta-style classical dance on adolescent self-regulation abilities in the Serat Wedharaga Version. The topic of the research and the research technique distinguish this research from the researchers' study. This study will investigate the concept of religious moderation education in the education 4.0 age, as determined by Serat Wedharaga's hermeneutic analysis. Many other studies adopt the inferred meaning of ancient Javanese writings or manuscripts such as studies by Mutiara Wandansari entitled "The Value of Moral Education in Serat Wasitadarma", "Moral Values in Serat Wedhatama," and "Character Education".12 These studies attempt to infer the underlying meaning, particularly when it comes to education, morals, or character. However, the major data source used in this study differs from the one we used since no journal publications covering Serat Wedharaga could be found using the Garuda portal, Moraref, and other journal indexing organizations.

Based on the findings of various prior research investigations, it can be determined that Serat Wedharaga, moderation education, and study connected to Education 4.0 have all been investigated. Although there have been many research

8 Elisabeth Pratidhina, "Education 4.0: Pergeseran Pendidikan Sebagai Konsekuensi Revolusi Industri 4.0," Humanika, Kajian Ilmiah Mata Kuliah Umum 20, no. 1 (November 10, 2020): 2.

${ }^{9}$ Edy Sutrisno, “Aktualisasi Moderasi Beragama Di Lembaga Pendidikan," Jurnal Bimas Islam 12, no. 2 (December 27, 2019): 326.

10 Muhammad Fikri, "Moderasi Pendidikan Pesantren Berbasis Perjumpaan Dalam Bayang-Bayang Radikalisme Di Lombok Nusa Tenggara Barat.," KOMUNIKE 11, no. 2 (December 16, 2019): 23.

11 Anggiastri Hanantyasari Utami, "Pengaruh Penerapan Falsafah Joged Mataram Dalam Tari Klasik Jawa Gaya Yogyakarta Terhadap Regulasi Diri Remaja Versi Serat Wedharaga" (Universitas Gadjah Mada, 2015), accessed on May 9, 2021, http:/ / etd.repository.ugm.ac.id/home/detail_pencarian/81406.

12 Sutrisna Wibawa, "Nilai-Nilai Moral Dalam Serat Wedhatama Dan Pendidikan Budi Pekerti," Jurnal Cakrawala Pendidikan 1, no. 3 (2010), accessed on May 9, 2021, https://journal.uny.ac.id/index.php/cp/article/view/237. 
outcomes on the same issue both locally and abroad, there has been no research that has explored Serat Wedharaga by hermeneutic studies. As a result, Serat Wedharaga's importance in Religious Moderation Education in the Education 4.0 Era is established. This study's guiding premise is global education based on local wisdom. This research stands out among other studies because of its added value. So, this study's perspective is a continuation of earlier relevant research, and this study looks for gaps or portions that have not been explored by other researchers.

\section{B. Research Method}

This study employs qualitative research methods. The researchers employ descriptive-analytic research to try to obtain the deepest understanding of the study subject, which in this case is the old text of Serat Wedharaga.

There are two types of data sources that will be prepared for this study: primary and secondary data sources. The Serat Wedharaga manuscript serves as the major data source in this study. Reading, evaluating, and analyzing many library catalogs that house old Javanese texts will provide this main data. Secondary data sources for this study include books, photographs, articles, journals, and the findings of previous studies that are relevant or connected to main data and research topics.

\section{The Formulation of Religious Moderation Education}

The Indonesian word "Pendidikan" is derived from the English word "Education,"13 which means "to enter something".14 This word is intended to put science and knowledge.

Education may also be defined as a process of mental, physical, and moral training to develop highly cultured humans. Education is also characterized in this context as an endeavor to develop one's personality and instill responsibility. Furthermore, education is stated to be an endeavor to supply vitamins for human growth so that excellent humans can be formed. ${ }^{15}$

Etymologically, moderate, or "wasathiyyah," is described as "medium" or "middle path". ${ }^{16}$ Wasathiyyah can also mean "not too much to the left or right".17 The notion of wasathiyyah will encourage Muslims to become wasathan or khairu ummah. 18 Terminologically, it refers to the delicate balance that exists between one's religious beliefs and tolerance. Aqidah comprises Islamic precepts, while tolerance is divided into two categories: tolerance among Muslims and tolerance among non-Muslims. ${ }^{19}$ As a

13 Päivi Gynther, "Basic Skills Provision for the Have-nots: A Rights Hoax? Reexamining International Standards on the Right to Education," International Journal of Inclusive Education 15, no. 8 (September 1, 2011): 851-864.

14 Hasan Langgulung, Asas-Asas Pendidikan Islam (Jakarta: Pustajka Al-Husna, 2000), 4.

${ }^{15}$ H.M Arifin, Ilmu Pendidikan Islam: Tinjauan Teoritis Dan Praktis Berdasarkan Pendekatan Interdisipliner (Jakarta: Bumi Aksara, 2014), 7.

16 Afifuddin Muhajir, Menalar Islam Moderat: Kajian Metodologis (Situbondo: Tanwirul Afkar, 2018), 5.

17 Tazul Islam and Amina Khatun, "'Islamic Moderation' in Perspectives: A

Comparison Between Oriental and Occidental Scholarships," International Journal of Nusantara Islam 3, no. 2 (June 28, 2015): 70.

${ }^{18}$ Azyumardi Azra, Relevansi Islam Wasathiyah: Dari Melindungi Kampus Hingga Mengaktualisasi Kesalehan (Jakarta: Kompas, 2020), 155.

19 S. Sofiuddin, "Transformasi Pendidikan Islam Moderat Dalam Dinamika Keumatan Dan Kebangsaan," Dinamika Penelitian: Media Komunikasi Penelitian Sosial Keagamaan 18, No. 2 (November 1, 2018): 353, https:/ / doi.org/10.21274/dinamika.2018.18.2.347-366. 
result, the moderate concept is "Rahmatan lil "alamin".

"Wasathiyah" means "moderate" in Islam. Wasathiyah is a way of life or a frame of mind that teaches us how to act and maintain a balanced pattern in all aspects of life. The word was popularized by Yusuf Al-Qardawy, a famous Muslim scholar. Through his attitude of tawadhu', he said that moderation is the result of a collaborative attitude of Islam itself which is then based on the religious attitude of a Muslim both from the dimensions of worship and muamalah, as well as the world and the hereafter.

The terms "moderate" and "moderatism," according to Hilmy, are nomenclature that is difficult to define since they are still strongly discussed by experts and scientists, and their definitions vary depending on the issue and the aspects in which they are comprehended. ${ }^{20}$ Burhani, in contrast to Hilmy, defines moderate in his writings by emphasizing the meaning of words, namely, "middle ground between liberalism and Islamism." This is defined by individuals or organizations that lie between liberalism and Islamism. ${ }^{21}$

We can find as many indicators of religious moderation as we can. The indicators of religious moderation, according to the Ministry of Religious Affairs' book "Moderation," are divided into four categories. These indicators are: "national commitment, tolerance, non-violence, and accommodating to local culture" ${ }^{22}$ These indicators will serve as a benchmark for how Indonesians apply moderation and the number of vulnerabilities they face.

\section{Education 4.0: Disruption of the World of Education}

The industrial revolution 4.0 is also known as the disruptive era. Disruption is defined as "things that are uprooted". ${ }^{23}$ If this term is applied to regular life, it signifies that a fundamental shift is taking place, notably the evolution of technology, which is addressing all gaps in human life. ${ }^{24}$ All demands and requirements, as well as the importance of the changes that occur in the period of disruption, necessitate a reaction. ${ }^{25}$

The era 4.0 or the Industrial revolution 4.0 was originally inspired by the theory of Claus Schwab in his book "The Fourth Industrial Revolution".26 In this book, he argued how the fourth industrial revolution will alter human mindsets, lifestyles, and ways of

${ }^{20}$ Masdar Hilmy, “"Whither Indonesia's Islamic Moderatism? A Reexamination On The Moderate Vision Of Muhammadiyah And NU" 7, No. 1 (2013): 25.

${ }^{21}$ Ahmad Najib Burhani, "Pluralism, Liberalism And Islamism: Religious Outlook Of The Muhammadiyah Islamic Movement In Indonesia" (Thesis, Manchester, University Of Manchester, 2007), 16.

${ }^{22}$ Kementrian Agama Republik Indonesia, Moderasi Beragama (Jakarta: Badan Litbang dan Diklat Kementerian Agama RI, 2019), 43.

23 KBBI Daring, "Hasil Pencarian Kata 'Disrupsi,'” accessed July 4, 2020, https://kbbi.kemdikbud.go.id/entri/disrupsi.

${ }^{24}$ Ali Fikri, "Pengaruh Globalisasi Dan Era Disrupsi Terhadap Pendidikan Dan NilaiNilai Keislaman," Sukma: Jurnal Pendidikan 3 (June 6, 2019): 120.

${ }^{25}$ Bukman Lian, "Revolusi Industri 4.0 Dan Disrupsi, Tantangan Dan Ancaman Bagi Perguruan Tinggi," Prosiding Seminar Nasional Program Pascasarjana Universitas PGRI Palembang 12, no. $01 \quad(22$ Februari 2019): 43, https://jurnal.univpgripalembang.ac.id/index.php/Prosidingpps/article/view/2512.

26 Abdul Rohman Dan Yenni Eria Ningsih, "Pendidikan Multikultural: Penguatan Identitas Nasional Di Era Revolusi Industri 4.0," Dalam Seminar Nasional Multidisiplin (Seminar Nasional Multidisiplin 2018tema A - Penelitian, Universitas Wahid Hasyim, 2018), 44. 
life to survive, as well as human relationships. ${ }^{27}$

Educational issues in the 4.0 era related to global and digital phenomena continue to be symptomatic. Digitalization and globalization cannot be stopped in any sector. To be able to regulate globalization at the economic level, one must use invention, commercialization, and competition. Ohmae's thinking, which is more economic, can be linked to education. Sufficient quality of resources is required to accomplish invention, commercialization, and competitiveness. ${ }^{28}$ We must not forget that, in addition to increasing the intellectuality of human resources, we must also pay attention to local wisdom that is in line with universal values that have long been upheld by religion and this nation as a guide, so that they are not swayed by the current strong digitalization and globalization era 4.0.

Education 4.0 is a new term that refers to a variety of meanings, including education in the digital era, ${ }^{29}$ futuristic educational visions, ${ }^{30}$ new learning systems, ${ }^{31}$ future education models, ${ }^{32}$ educational ecosystems for the future, ${ }^{33}$ current learning systems with a variety of technologies and teaching methods, and a new era for a new society. ${ }^{34}$ Each of these terms is defined according to the expert's perspective on how to respond to the 4.0 age. Despite the differences in terminology, education 4.0 is a concept that emphasizes the significance of revamping the present educational system to meet the expectations of a more inventive society in the digital age. ${ }^{35}$

Education 4.0, according to Dunwill, is the era of using technology in the context of teaching and learning. This is because technology allows human-machine contact to be perceived as synergistic, which adds to the industrial revolution century's accelerated invention. Education 4.0 was created to prepare students for the future. Education 4.0 is a new way of viewing teaching and learning that incorporates the sophistication of information and communication technologies into every step of the

${ }^{27}$ R. Willya Achmad Dkk., "Potret Generasi Milenial Pada Era Revolusi Industri 4.0," Focus : Jurnal Pekerjaan Sosial 2, No. 2 (2019): 188, Https://Doi.Org/10.24198/Focus.V2i2.26241.

28 Suwarjo, "Penguatan Karakter Peserta Didik Dalam Menghadapi Era Digital," Dalam Prosiding Konferensi Pendidikan Nasional, 2018, 4.

${ }_{29}$ Anas Abdelrazeq dkk., "Teacher 4.0: Requirements Of The Teacher Of The Future In Context Of The Fourth Industrial Revolution," 2016, 8221-26, https://doi.org/10.21125/iceri.2016.0880.

${ }^{30}$ C.C. Chea and J.T.J Huan, "Higher Education 4.0: The Possibilities and Challenges," Journal of Social Sciences and Humanities 5, no. 2 (2019).

31 Dr Vichian Puncreobutr, "Education 4.0: New Challenge of Learning," St. Theresa Journal of Humanities and Social Sciences 2, no. 2 (December 31, 2016), accessed August 8, 2021, http://www.stic.ac.th/ojs/index.php/sjhs/article/view/Position\%20Paper3.

32 Aida Aryani Shahroom and Norhayati Hussin, "Industrial Revolution 4.0 and Education," International Journal of Academic Research in Business and Social Sciences 8, no. 9 (October 13, 2018): 314-319.

33 Srivastava, A. K, "Is Education 4.0 the Future of Learning?," India Today, accessed August 8, 2021, https://www.indiatoday.in/education-today/featurephilia/story/iseducation-4-0-the-future-of-learning-1557292-2019-06-27.

34 Sunan Sripai, Jesada Boonmahome, and Jitirat SaengLoetuthai, "Indicators of the Characteristics of the Graduates of Rajabhat Universities at the Leap Frogging to the Education 4.0," International Journal of Science and Research (IJSR) 7, no. 10 (2018).

${ }^{35}$ Mahrus As'ad, "Adaptation Into Islamic Education 4.0: An Approach To Redesigning A Sustainable Islamic Education In The Post Pandemic Era," AKADEMIKA: Jurnal Pemikiran Islam 26, no. 1 (May 20, 2021): 19-42. 
process. ${ }^{36}$ According to Fisk, there is a new vision of education. To increase technology in learning and encourage active learning, learning is primarily focused on building digital technology capabilities at all levels. ${ }^{37}$

After various experts defined education 4.0, we may unveil the definition of education 4.0. Education 4.0, also known as education 4.0, is a new educational formulation that combines digital technology, the sophistication of scientific and technological discoveries, and all instruments in the world of education, such as curriculum, educators, students, learning technology, learning media, and so on, to achieve educational goals and assist students in preparing for the Fourth Industrial Revolution.

Education 4.0, or education in the 4.0 age, is about more than just having the latest technology; it also involves preparing Indonesian education to be more sophisticated and adaptive to this period. Improvements are required in areas such as attitude, values, and mindset. 38 As a result, we today require a curriculum that is capable of developing essential human abilities such as language, creativity, and spirituality.

\section{E. Serat Wedharaga}

In addition to his spectacular work, Serat Kalatidha, Raden Ranggawarsita also published Serat Wedharaga. The words "Wedha" and "body," which both imply "body, self," were the forerunners of the term "Wedharaga." 39 Wedharaga is regarded as a "selfguidance book" based on its word structure.

The song of Serat Wedharaga is available in two versions: Gambuh and Pangkur. Both are kept at Yogyakarta's Pura Pakualaman Library. Manuscripts containing the tembang (song) Pangkur, which is not well-known among the general audience, have been severely damaged by time. As a result, Serat Wedharaga, which is still popular today, is a version of the Gambuh song.

The Gambuh song variant, Serat Wedharaga, is made up of 38 stanzas with provisions such as those found in the Gambuh song. Each stanza has a total of five Guru Gatra. The rules of Guru Wilangan and Guru Tembang 7u 10u 12i 8u 8o bind one stanza. Based on the Chandrasengkala written in the last verse, "tursan rong sapteng lebu," Serat Wedharaga was undoubtedly composed around 1799 or 1870 AD.

Serat Wedharaga opens with the poet's advice, telling of a young man whose heart has been blocked by darkness. He had already entered the land of darkness and had broken a number of social conventions. He lusted because he considered himself to be an all-rounder. Ranggawarsita responded by advising people not to live like this. The poet's advice in this song is such as not being arrogant, having tolerance, and being humble, as well as the spiritual dilemma of divinity.

36 Giorgos Panagiotopoulos and Zoe Karanikola, "Education 4.0 and Teachers: Challenges, Risks and Benefits" (December 1, 2020): 1857-7881.

37 Rasika Lawrence, Lim Fung Ching, and Haslinda Abdullah, "Strengths and Weaknesses of Education 4.0 in the Higher Education Institution," International Journal of Innovative Technology and Exploring Engineering (IJITEE) 9, no. 2 (2019).

${ }^{38}$ Astuti Astuti, S. B. Waluya, Dan M. Asikin, "Strategi Pembelajaran Dalam Menghadapi Tantangan Era Revolusi Industri 4.0," Prosiding Seminar Nasional Pascasarjana (Prosnampas) 2, No. 1 (2019): 471.

39 Pardi Suratno et al., Karakter Manusia Dalam Karya Raden Ngabehi Ranggawarsita (Semarang: Balai Bahasa Provinsi Jawa Tengah, 2015), 93. 


\section{F. Hermeneutic Analysis of Serat Wedharaga and Its Relevance to Religious Moderation Education in the Era of Education 4.0}

Serat Wedharaga is included in Piwulang's Literary Works. This work is an interesting application and calculation of various kinds of knowledge in religion, spiritual ethics, and other social sciences. After we identified the contents of all thirtyeight verses, we found various explanations regarding the messages, especially for the younger generation. Even as the years pass, the essence of youth as the nation's future generation stays the same: those who can manage their passions and emotions and align themselves with the Divine.

We discovered two crucial ideas in education that Raden Ranggawarsita sought to impart in Serat Wedharaga after doing further investigation. These two aspects, in our opinion, are very much relevant to Serat Wedharaga's work on religious moderation education in the education 4.0 era.

\section{Andragogy Education}

One of the catalysts for the establishment of a type of education that invites the public and scholars to play a role that has never been played before is innovative thinking. Cross-cultural negotiations, as well as alternative understandings in the process of creating public understanding, are required in response to global issues to take a stand, stimulate, challenge, empower, and offer a way forward for an understanding that can respond to the principle of moderation.

The implementation of moderate Islamic religious beliefs requires a systematic approach involving a huge teaching and learning process using a variety of modalities. One way to achieve actualization is to use andragogy with a transformational perspective, altering the mentality that relates to growth in the realms of cognition, affection, and skills so that the nation's generation develops a moderate attitude. In this scenario, the most successful socialization is achieved through the use of the educational route and andragogy ${ }^{40}$ in the delivery process.

By employing the primary role of humans in critical reflection that adults can accomplish, the transformation of the concept of moderation bridges the gap between radical understanding and moderation. This phenomenon demonstrates the existence of a dialogical process between assumptions and meanings, which is often only grasped textually, resulting in an anti-moderation understanding. ${ }^{41}$ Adults are the only ones who can detect the paradigmatic assumptions in their thinking through a process known as "self-awareness."

According to Ranggawarsita on Serat Wedharaga, Individual growth and development must be in line with age maturity concerns. He talked extensively about the term "shaman" in Serat Wedharaga, which he considered to be a taboo issue for a young man. Ranggawarsita did not dismiss a young man; in reality, it is not a restriction; nonetheless, he contrasted it with moral load and social obligation issues.

Human growth and development must take place in line with his or her age. In the third stanza, it is taught that a young man must live by the principle of developing self-competence by exerting maximum effort. Rangwarsita thought that youth should develop self-awareness through the logic of incremental action.

40 John A. Henschke, "Considerations Regarding the Future of Andragogy," Adult Learning 22, no. 1 (January 1, 2011): 34.

41 Jasminto, "Urgensi Teori Andragogi Dalam Memperkuat Visi Moderat Islam Di Indonesia," in 2nd Procedings (Presented at the Annual Conference For Muslim Scholars, Surabaya: UIN Sunan Ampel Surabay, 2018). 
Based on the statement above, self-control via physical, mental, and spiritual strength training is an endeavor to increase individual self-awareness. We may even claim that the aspect of independence is the most essential one used here. However, in Ranggawarsita's opinion, this self-direction process does not necessarily provide a person the freedom to act. In this Serat Wedharaga, self-direction is used with unique requirements that must be regarded by youth or pupils when navigating education.

The first thing that becomes the benchmark is that knowledge and various skills are always under etiquette. Many young individuals with personalities prefer to conjure up images of all-rounders on occasion. Ranggawarsita coined the phrase "daya linuwih" to describe a person's ability that their knowledge and skill can be realized, applied, and felt by many people.

If a person's kawruh (knowledge) and laku (behavior) are combined, he will understand that science is a tool or method for socializing in a multicultural society. Adab (attitude) and manners are more important than science and knowledge. Raden Ranggawarsita encourages young people in this work to not allow their newfound knowledge blind them to the importance of etiquette, kawruh (knowledge), and unggahungguh (manners) as human beings in society.

Humility is equally crucial in the acquisition and development of knowledge. Raden Ranggawarsita related the story of an intelligent young man who debated with his elderly grandpa in the stanzas of Serat Wedharaga. This story is a sociological criticism of how a young guy must still respect those who are older than him. The young guy's knowledge lacked the practical experience of the older man. When comparing the young man and the grandfather, the young man is still on the theoretical level when it comes to observing world phenomena, but the grandfather is far and deep in the practical level of life.

Critical reflection plays a vital function in the learning process. Raden Ranggawarsita in his work was able to convey the phenomenological aspect of human life, which is rarely related to data, facts, and truth. His habit of seeing, thinking, and acting made him aware of the significance of his perceptions and actions. Adults will be more conscious of how to appear, think, and act in every constructive habit as a result of this reflectiveness. Adults will utilize relativity to evaluate the efficacy of their perceptions, ideas, and behaviors, as well as the causes of their ineffective ways. His habits will be formed as a result of his reflection on topics that are intriguing to him. In the 32nd stanza, this is demonstrated.

According to the story, after a young guy met with his elderly grandfather, the young man recovered from his haughty clever persona. He then went on to expand his expertise, study it, and perfect it. He studied his knowledge to the experts. What he expanded on was the concept of the "empan papan," which refers to the capacity to act and situate oneself in the appropriate place and time.

\section{Self-Regulation}

In his books, Bandura explains the concept of self-regulation. He defines selfregulation as a person's ability to put and govern his personality and his surroundings, establish cognitive support, and provide both support and punishment for himself. ${ }^{42}$ Human behavior can be influenced by both internal and external forces. ${ }^{43}$ External

\footnotetext{
${ }^{42}$ Jan M. Burg, Oliver T. Wolf, and Johannes Michalak, "Mindfulness as Self-Regulated Attention," Swiss Journal of Psychology 71, no. 3 (January 1, 2012): 135-139.

${ }^{43}$ Monique Boekaerts, "Self-Regulated Learning: Where We Are Today," International Journal of Educational Research 31, no. 6 (January 1, 1999): 445-457.
} 
factors can have an impact on a person's conduct by placing oneself as a source of selfevaluation ${ }^{44}$ and reinforcement. ${ }^{45}$ Internal factors then shape behavior through three steps: self-observation, behavior appraisal, and self-response.

When responding to community problems, the adequacy of the explanation and the management that will be carried out will be addressed. Many critics believe that some western ideologies are unsuitable for application in every aspect of Asian civilization, particularly in Indonesia. ${ }^{46}$ Many of the educational, psychological, and social sciences used in Indonesia have been based on Western theories. As a result, an in-depth study of sincerity, tepa slira (tolerance), awas and eling (cautiousness), and ignoring the rumors contained in the Serat Wedharaga as an effort to teach pitutur luhur (noble advice) as a basis for explanation related to efforts to initiate religious moderation education in the era of manuscript-based education 4.0 has been conducted.

\section{a) Sincerity}

Sincerity is a term used to describe a person's capacity to let up of their individuality or self-interest to adapt to the grand harmony that God has established in the universe. ${ }^{47}$ Sincerity in Javanese culture is expressed in the proverb "wani ngalah dhuwur wekasane, andhap asor, lembah manah". 48 Andhap asor is also known as lembah manah, which means "humble" and "not arrogant." 49 Both may exist at the same time as a way of appreciating the importance of being modest and not arrogant, especially for the Javanese people. A person's humility may be seen in their conduct, which includes obeying unggah-ungguh (etiquette), not being arrogant, not underestimating others, and so on. The third verse contains the message of sincerity. The stanza highlights the importance of being truthful in every situation and relying on God for all that has transpired. The phrase "Aja kibir" reminds humans not to be arrogant because they are simply small and weak creatures. Furthermore, the advice to be sincere is also found in the 6th stanza with a focus on the phrase "andhap asor".

Sincerity is not defined as giving up, losing, or submitting without regard for logic and moral awareness. Sincerity and willingness are ways of expressing one's wish to be free of all lusts, including wrath, rage, and the desire for vengeance. If left unrestrained, lust may devastate harmony, order, tolerance, and peace.

\section{b) Tepa Slira (Tolerance)}

Tepa slira is a Javanese term that describes a person's attitude toward other people in society. ${ }^{50}$ Tepa is derived from the term "tepa," which means "to position", and slira, which means "body." As a result, the literal definition of tepa slira is "to position

${ }^{44}$ Darren H. Iwamoto et al., "Self-Regulated Learning as a Critical Attribute for Successful Teaching and Learning," International Journal for the Scholarship of Teaching and Learning 11, no. 2 (July 2017), accessed November 22, 2021, https:/ / eric.ed.gov/ ?id=EJ1150528.

45 Albert Bandura, Self Regulation Of Motivation And Action Through Goal Systems, n.d.

46 Nasiwan, Seri Teori-Teori Sosial Dunia (Yogyakarta: UNY Press, 2016), 10.

47 Frans Magnis Suseno, Etika Jawa, Sebuah Analisis Falsafi Tentang Kebijaksanaan Hidup Jawa (Jakarta: Gramedia Pustaka Utama, 2001).

48 G. Banyuadhi, Eling Lan Waspada Wejangan Leluhur Jawa Demi Menggapai Kebahagiaan Sejati (Yogyakarta: Saufa, 2015).

49 Warih Jatirahayu, "Kearifan Lokal Jawa Sebagai Basis Karakter Kepemimpinan," DIKLUS 17, no. 1 (2013): 276, https:/ /journal.uny.ac.id/index.php/diklus/article/view/2895.

50 Aldila Dyas Nurfitri, Revitalisasi Toleransi Beragama Berbasis Kearifan Lokal (Semarang: Penerbitan Universitas Katholik Soegijapranata, 2017), 58. 
(something) on the human body." Tepa slira is defined by Suseno as the attitude of people who can regulate themselves based on self-awareness, which is the foundation for positioning oneself in social relationships based on self-decision and voluntary heart. 51 Furthermore, the repercussions of humans' status as social beings need interaction with others. Tepa slira then presents itself in conduct to sustain positive relationships in all areas.

Tepa slira is defined as a person's predisposition to respect others, empathize, be self-aware, be sensitive, and comprehend the needs of others in terms of religion and belief to generate peace, social harmony, and world harmony in the context of religious moderation. In addition, Raden Ranggawarsita, a prominent Javanese poet, embeds tepa slira advice in Serat Wedhatama's work, which is expressed in the 25th stanza.

According to Kamajaya, "Kembang Tepus" is a type of flower. Then "tepus" is defined as tepa, a thing's length or area.52 So, the meaning of "Kembang Tepus" is the existence of advice to act and do by using the measure of oneself. It becomes tepa salira in the proverb. The term "panuju," on the other hand, means "something that stimulates the heart to agree on a certain object or goal." This gatra implies that anyone who can know himself (self-introspection) and implement tepa salira in his/her life would be able to generate harmony in the environment around them.

Tepa slira is a term used to describe the process of overcoming and letting go of blind altruism and egoism to avoid acting arbitrarily on others. This term also refers to a loving and compassionate attitude, as well as a true and responsible attitude in the community's social life. Tepa slira, as an expression, also advocates a tolerant attitude to achieve peace and harmony in life, particularly in the diverse world of belief and religion.

\section{c) Awas lan Eling (Cautious)}

Raden Ranggawarsita always tells his readers to be "aware and vigilant." Cautiousness is defined as the ability to recall oneself and transcend human limits in the face of all detrimental things. "Eling" (to remember) is a reminder addressed inside oneself. Meanwhile, "awas" (cautiousness) is focused toward the outside of people in order to deal with external temptations and impediments. The advice to always be aware and watchful is found in the 7th and 25th stanzas of Serat Wedharaga.

Eling is defined as remembering to be aware at all times, while awas is defined as being cautious (alert) in all steps. ${ }^{3}$ As a result, eling might be regarded as a human being who consciously recalls religious norms, respects and obeys societal norms. Meanwhile, awas can be defined as being always cautious in speaking and acting to avoid making mistakes or causing conflicts.

The admonition to be "cautious and alert" at all times becomes guidance in dealing with numerous life issues. The problems/trials that are meant are not just "sad," but also "pleasant." "Sad" trials are those that cause agony, but "pleasant" trials are those temptations that entice and shatter faith. As described in the 16th stanza, if these hardships are not surmounted, they might lead individuals to humiliation and disgrace:

"Wong ngaurip wus tamtu,

Akeh padha arebut piyangkuh

51 Suseno, Etika Jawa, Sebuah Analisis Falsafi Tentang Kebijaksanaan Hidup Jawa.

52 Kamajaya, Lima Karya Pujangga Ranggawarsita (Jakarta: Balai Pustaka, 1991).

53 Novita Siswayanti, "Javanese Ethical Values In Tafsir Al-Huda," Analisa 20 (7 Desember 2013): 214, Https:/ /Doi.Org/10.18784/ Analisa.V20i2.177. 
Lumuh lamun kasor kaseser sathithik.

Nanging singa peksa unggul,

Ing wekasan dadi asor."

People, definitely, live

fighting for pride,

not wanting to lose

(and) shifting a little,

but whoever forces to excel,

will end up being humiliated.

\section{d) Ignoring rumors}

Today, rumors are referred to as hoaxes. A hoax is a term that denotes "deception, deception, fake news, or rumors" in English.54 The term "hoax" refers to information that cannot be verified.

The term "hoax" refers to false information or an attempt to trick the recipient of the information into believing something. ${ }^{55} \mathrm{~A}$ hoax can also be interpreted with information that is not a fact because the definition of information is a factual collection of data. ${ }^{56}$ In addition, fake news, hearsay, or hoax is defined as a plan to deceive someone, especially by playing someone, or a trick done to deceive someone with information that does not match the existing reality. ${ }^{57}$ The most common misconception regarding hearsay is whether the information is a fraud or hoax, which refers to fake news that is not based on facts or reality.

Although there is no specific mention of fake news or hoaxes in Serat Wedhatama, it is emphasized in the 21st stanza to be wary of persons with charming looks and those who engage in riots.

As we know that 4.0 era is an era filled with an abundance of information. The internet, which has now become a basic necessity for people, provides a wealth of information from many sources. The ease with which individuals can obtain information via social media and other forms of media makes it simpler for them to be exposed to both beneficial and non-useful information. To respond to all circulating information in the middle of this wealth of knowledge, a wise mindset is required.

It is critical to have a mindset that does not believe in rumors or hoaxes. It is not permitted to just believe the information that is accessible in the middle of a diversified Indonesian society and a plethora of information. To be able to believe the news that is provided, efforts are required. This is because many people aim to sever the unity of Muslims and the Indonesian country.

\section{G. Conclusion}

After conducting an in-depth study related to religious moderation education in the education 4.0 era as well as a hermeneutic analysis of Serat Wedharaga, we can

54 Adami Chazawi and Ardi Ferdian, Tindak Pidana Pemalsuan (Jakarta: PT Rajagrafindo Persada, 2016), 236.

55 Christiany Juditha, "Hoax Communication Interactivity in Social Media and Anticipation (Interaksi Komunikasi Hoax di Media Sosial serta Antisipasinya)," Jurnal Pekommas 3, no. 1 (September 12, 2018): 33.

56 Akhmad Shunhaji, "Pendidikan Anti Hoaks Era 4.0 Perspektif Al-Qur'an," Jurnal Online Studi Al-Qur an 16 (January 31, 2020): 39.

57 Ibid. 
conclude that there are educational values in Serat Wedharaga such as andragogy education and the value of self-regulation, which includes a sincere attitude, tepasalira (tolerance), awas lan eling (cautiousness), and ignoring hearsay. Serat Wedharaga's educational ideals are relevant to the 4.0 era's concept of religious moderation education.

\section{H. Acknowledgments}

The authors would like to thank everyone who was involved from the beginning until the end of the process. This includes our colleagues who gave feedbacks, as well as the editorial board and the reviewers who handled the manuscript and provided valuable insights in improving it further.

\section{Author Contributions Statement}

All of authors worked together on the idea and the problem related to the topic. K and DW developed the theory. Furthermore, NW and FMA verified the analytical methods. Then all of authors investigated and supervised the findings of this work. All of authors wrote and edited the manuscript [.]

\section{REFERENCES}

Abdelrazeq, Anas, Daniela Janssen, Christian Tummel, Anja Richert, and Sabina Jeschke. "Teacher 4.0: Requirements Of The Teacher Of The Future In Context Of The Fourth Industrial Revolution." 8221-8226, 2016.

Achmad, R. Willya, Marcelino Vincentius Poluakan, Didin Dikayuana, Herry Wibowo, and Santoso Tri Raharjo. "Potret Generasi Milenial Pada Era Revolusi Industri 4.0." Focus : Jurnal Pekerjaan Sosial 2, no. 2 (2019): 187-197.

Adami Chazawi, and Ardi Ferdian. Tindak Pidana Pemalsuan. Jakarta: PT Rajagrafindo Persada, 2016.

Arifin, H.M. Ilmu Pendidikan Islam: Tinjauan Teoritis Dan Praktis Berdasarkan Pendekatan Interdisipliner. Jakarta: Bumi Aksara, 2014.

As'ad, Mahrus. "Adaptation Into Islamic Education 4.0: An Approach To Redesigning A Sustainable Islamic Education In The Post Pandemic Era." AKADEMIKA: Jurnal Pemikiran Islam 26, no. 1 (May 20, 2021): 19-42.

Astuti, Astuti, S. B. Waluya, and M. Asikin. "Strategi Pembelajaran Dalam Menghadapi Tantangan Era Revolusi Industri 4.0." Prosiding Seminar Nasional Pascasarjana (PROSNAMPAS) 2, no. 1 (2019): 469-473.

Azra, Azyumardi. Relevansi Islam Wasathiyah: Dari Melindungi Kampus Hingga Mengaktualisasi Kesalehan. Jakarta: Kompas, 2020.

Bandura, Albert. Self Regulation Of Motivation And Action Through Goal Systems, n.d.

Banyuadhi, G. Eling Lan Waspada Wejangan Leluhur Jawa Demi Menggapai Kebahagiaan Sejati. Yogyakarta: Saufa, 2015.

Boekaerts, Monique. "Self-Regulated Learning: Where We Are Today." International Journal of Educational Research 31, no. 6 (January 1, 1999): 445-457.

Burg, Jan M., Oliver T. Wolf, and Johannes Michalak. "Mindfulness as Self-Regulated Attention." Swiss Journal of Psychology 71, no. 3 (January 1, 2012): 135-139.

Burhani, Ahmad Najib. "Pluralism, Liberalism and Islamism: Religious Outlook of the Muhammadiyah Islamic Movement in Indonesia." Thesis, University of Manchester, 2007. 
C.C. Chea, and J.T.J Huan. "Higher Education 4.0: The Possibilities and Challenges." Journal of Social Sciences and Humanities 5, no. 2 (2019).

Elma Haryani. "Pendidikan Moderasi Beragama Untuk Generasi Milenia: Studi Kasus Lone Wolf" Pada Anak Di Medan." DUKASI: Jurnal Penelitian Pendidikan Agama Dan Keagamaan 18, no. 2 (2020). https:/ / doi.org/10.32729/edukasi.v18i2.710.

Fikri, Ali. "Pengaruh Globalisasi Dan Era Disrupsi Terhadap Pendidikan Dan NilaiNilai Keislaman." Sukma: Jurnal Pendidikan 3 (June 6, 2019): 117-136.

Fikri, Muhammad. "Moderasi Pendidikan Pesantren Berbasis Perjumpaan Dalam Bayang-Bayang Radikalisme Di Lombok Nusa Tenggara Barat." KOMUNIKE 11, no. 2 (December 16, 2019): 22-37.

Gynther, Päivi. "Basic Skills Provision for the Have-nots: A Rights Hoax? Reexamining International Standards on the Right to Education." International Journal of Inclusive Education 15, no. 8 (September 1, 2011): 851-864.

Henschke, John A. "Considerations Regarding the Future of Andragogy." Adult Learning 22, no. 1 (January 1, 2011): 34-37.

Hilmy, Masdar. "Whither Indonesia's Islamic Moderatism? A Reexamination on the Moderate Vision of Muhammadiyah and NU" 7, no. 1 (2013).

Islam, Tazul, and Amina Khatun. "'Islamic Moderation' in Perspectives: A Comparison Between Oriental and Occidental Scholarships." International Journal of Nusantara Islam 3, no. 2 (June 28, 2015): 69-78.

Iwamoto, Darren H., Jace Hargis, Richard Bordner, and Pomaika' inani Chandler. "SelfRegulated Learning as a Critical Attribute for Successful Teaching and Learning." International Journal for the Scholarship of Teaching and Learning 11, no. 2 (July 2017). Accessed November 22, 2021. https:// eric.ed.gov/?id=EJ1150528.

Jasminto. "Urgensi Teori Andragogi Dalam Memperkuat Visi Moderat Islam Di Indonesia." In 2nd Procedings. Surabaya: UIN Sunan Ampel Surabay, 2018.

Jatirahayu, Warih. "Kearifan Lokal Jawa Sebagai Basis Karakter Kepemimpinan." Diklus 17, No. 1 (2013). Accessed September 14, 2021. https://journal.uny.ac.id/index.php/diklus/article/view/2895.

Juditha, Christiany. "Hoax Communication Interactivity in Social Media and Anticipation (Interaksi Komunikasi Hoax di Media Sosial serta Antisipasinya)." Jurnal Pekommas 3, no. 1 (September 12, 2018): 31-44.

Kamajaya. Lima Karya Pujangga Ranggawarsita. Jakarta: Balai Pustaka, 1991.

Kamidjan. "Wacana Serat Hardamudha (Kearifan Lokal Dalam Sastra Jawa)." Linguistika: Buletin Ilmiah Program Magister Linguistik Universitas Udayana 19, no. 2 (September https://ojs.unud.ac.id/index.php/linguistika/article/view/9694.

KBBI Daring. "Hasil Pencarian Kata 'Disrupsi.'” Accessed July 4, 2020. https://kbbi.kemdikbud.go.id/entri/disrupsi.

Kementrian Agama Republik Indonesia. Moderasi Beragama. Jakarta: Badan Litbang dan Diklat Kementerian Agama RI, 2019.

Kosasih, Engkos. "Literasi Media Sosial Dalam Pemasyarakatan Sikap Moderasi Beragama." Jurnal Bimas Islam 12, no. 2 (December 27, 2019): 263-296.

Langgulung, Hasan. Asas-Asas Pendidikan Islam. Jakarta: Pustajka Al-Husna, tt.

Lase, Delipiter. "Pendidikan Di Era Revolusi Industri 4.0." SUNDERMANN: Jurnal Ilmiah Teologi, Pendidikan, Sains, Humaniora dan Kebudayaan 12, no. 2 (November 7, 2019): 28-43.

Lawrence, Rasika, Lim Fung Ching, and Haslinda Abdullah. "Strengths and Weaknesses of Education 4.0 in the Higher Education Institution." International Journal of Innovative Technology and Exploring Engineering (IJITEE) 9, no. 2 (2019). 
Lian, Bukman. "Revolusi Industri 4.0 Dan Disrupsi, Tantangan Dan Ancaman Bagi Perguruan Tinggi." Prosiding Seminar Nasional Program Pascasarjana Universitas PGRI Palembang 12, no. 01 (February 22, 2019). Accessed July 4, 2020. https://jurnal.univpgripalembang.ac.id/index.php/Prosidingpps/article/view/2512.

Majidah, Dian Hasfera, and M. Fadli. "Keterampilan Literasi Informasi Mahasiswa Dalam Menghadapi Revolusi Industri 4.0." Al-Maktabah: Jurnal Perpustakaan, Arsip Dan Dokumentas 11, no. 1 (2019).

Muhajir, Afifuddin. Menalar Islam Moderat: Kajian Metodologis. Situbondo: Tanwirul Afkar, 2018.

Nasiwan. Seri Teori-Teori Sosial Dunia. Yogyakarta: UNY Press, 2016.

Nurfitri, Aldila Dyas. Revitalisasi Toleransi Beragama Berbasis Kearifan Lokal. Semarang: Penerbitan Universitas Katholik Soegijapranata, 2017.

Panagiotopoulos, Giorgos, and Zoe Karanikola. "Education 4.0 and Teachers: Challenges, Risks and Benefits" (December 1, 2020): 1857-7881.

Permana, Chinda Pandu, and Endang Nurhayati. "Ragam Bahasa Serat Kalatidha Serta Relevansinya Dalam Pembelajaran Bahasa Jawa Siswa SMP Negeri 7 Yogyakarta." LingTera 1, no. 1 (2014). https:// doi.org/10.21831/lt.v1i1.2468.

Pratidhina, Elisabeth. "Education 4.0: Pergeseran Pendidikan Sebagai Konsekuensi Revolusi Industri 4.0." Humanika, Kajian Ilmiah Mata Kuliah Umum 20, no. 1 (November 10, 2020): 1-12.

Puncreobutr, Dr Vichian. "Education 4.0: New Challenge of Learning." St. Theresa Journal of Humanities and Social Sciences 2, no. 2 (December 31, 2016). Accessed August 8 ,

2021. http://www.stic.ac.th/ojs/index.php/sjhs/article/view/Position\%20Paper3.

Rohman, Abdul, and Yenni Eria Ningsih. "Pendidikan Multikultural: Penguatan Identitas Nasional Di Era Revolusi Industri 4.0." In Seminar Nasional Multidisiplin. Universitas Wahid Hasyim, 2018.

Seaman, Jayson. "Experience, Reflect, Critique: The End of the 'Learning Cycles' Era." Journal of Experiential Education 31, no. 1 (August 1, 2008): 3-18.

Shahroom, Aida Aryani, and Norhayati Hussin. "Industrial Revolution 4.0 and Education." International Journal of Academic Research in Business and Social Sciences 8, no. 9 (October 13, 2018): 314-319.

Shunhaji, Akhmad. "Pendidikan Anti Hoaks Era 4.0 Perspektif Al-Qur'an." Jurnal Online Studi Al-Qur an 16 (January 31, 2020): 37-54.

Siswayanti, Novita. "Javanese Ethical Values in Tafsir Al-Huda." Analisa 20 (December 7, 2013): 207.

Sofiuddin, S. "Transformasi Pendidikan Islam Moderat Dalam Dinamika Keumatan Dan Kebangsaan." Dinamika Penelitian: Media Komunikasi Penelitian Sosial Keagamaan 18, no. 2 (November 1, 2018): 347-366-366.

Sripai, Sunan, Jesada Boonmahome, and Jitirat SaengLoetuthai. "Indicators of the Characteristics of the Graduates of Rajabhat Universities at the Leap Frogging to the Education 4.0." International Journal of Science and Research (IJSR) 7, no. 10 (2018).

Srivastava, A. K. "Is Education 4.0 the Future of Learning?" India Today. Accessed August 8, 2021. https://www.indiatoday.in/educationtoday/featurephilia/story/is-education-4-0-the-future-of-learning-1557292-201906-27. 
Suprayitno, Edy. "Etika Pengembaraan Ilmu Masyarakat Jawa Pada Naskah Serat Dewa Ruci Karya R. Ng. Yasadipura I Dalam Perspektif Kehidupan Modern." LINGUA : Jurnal Bahasa, Sastra, dan Pengajarannya 14, no. 2 (2017).

Suratno, Pardi, Kustri Sumiyardana, Muchammad Fikri, and Drajat Agus Murdowo. Karakter Manusia Dalam Karya Raden Ngabehi Ranggawarsita. Semarang: Balai Bahasa Provinsi Jawa Tengah, 2015.

Suseno, Frans Magnis. Etika Jawa, Sebuah Analisis Falsafi Tentang Kebijaksanaan Hidup Jawa. Jakarta: Gramedia Pustaka Utama, 2001.

Sutrisno, Edy. "Aktualisasi Moderasi Beragama Di Lembaga Pendidikan." Jurnal Bimas Islam 12, no. 2 (December 27, 2019): 323-348.

Suwarjo. "Penguatan Karakter Peserta Didik Dalam Menghadapi Era Digital." In Prosiding Konferensi Pendidikan Nasional, 2018.

Utami, Anggiastri Hanantyasari. "Pengaruh Penerapan Falsafah Joged Mataram Dalam Tari Klasik Jawa Gaya Yogyakarta Terhadap Regulasi Diri Remaja Versi Serat Wedharaga." Universitas Gadjah Mada, 2015. Accessed May 9, 2021. http://etd.repository.ugm.ac.id/home/detail_pencarian/81406.

Wibawa, Sutrisna. "Nilai-Nilai Moral Dalam Serat Wedhatama Dan Pendidikan Budi Pekerti." Jurnal Cakrawala Pendidikan 1, no. 3 (2010). Accessed May 9, 2021. https://journal.uny.ac.id/index.php/cp/article/view/237.

Widyatwati, Ken. "Nilai-Nilai Luhur Pujangga Jawa Dalam Serat Sana Sunu." HUMANIKA 16, no. 9 (2012). https:/ / doi.org/10.14710/humanika.16.9. 